\title{
SOSIALISASI PEMANFAATAN LIMBAH KULIT DURIAN SEBAGAI PRODUK BRIKET DI WILAYAH WARGA RT. 19 KELURAHAN 1 ILIR KECAMATAN ILIR TIMUR II PALEMBANG SUMATERA SELATAN
}

\author{
Lety Trisnaliani $^{1}$, Ahmad Zikri ${ }^{2}$, dan Erlinawati Akil ${ }^{3}$ \\ ${ }^{1}$ Program Studi D-IV Teknik Energi Jurusan Teknik Kimia Politeknik Negeri Sriwijaya \\ E-mail : Lety.trisnaliani@polsri.ac.id \\ ${ }^{2}$ Program Studi D-IV Teknik Energi Jurusan Teknik Kimia Politeknik Negeri Sriwijaya \\ E-mail : zikri90@gmail.com \\ ${ }^{3}$ Program Studi D-IV Teknik Kimia Jurusan Teknik Kimia Politeknik Negeri Sriwijaya \\ E-mail : erlinawatiakil@yahoo.com
}

\begin{abstract}
Durian waste is the basic ingredient of making this briquette and just piling up into waste in the neighborhood where it sells and can not provide economic value. Now the material we used to call environmental waste will turn into alternative fuels. Through the process of processing, durian waste will be fuel in the form of briquettes and this product will have a fairly high selling value. The briquettes also smell good when used, making them suitable for the food industry, both large and large scale. Because of these several advantages, durian leather briquettes have wide open market potential in both local, domestic and export markets. The method implemented is to socialize the utilization of durian skin by spreading knowledge with the manufacture and processing of durian skin so as to produce the outcome of durian briquette product as a substitute of fuel in the era of expensive energy.
\end{abstract}

Keywords : Durian Waste, Bricket, Alternative Energy, Economic Value

\section{Pendahuluan}

Krisis ekonomi dunia saat ini berpengaruh terhadap kenaikan harga minyak dan gas bumi yang digunakan sebagai sumber energi pada berbagai industri kecil dan menengah. Hal ini mengakibatkan biaya produksi dan operasional semakin tinggi. Oleh karena itu perlu dicari bahan bakar pengganti yang lebih murah, mudah dioperasikan, dan aman terhadap dampak lingkungan. Semakin menipisnya persediaan minyak bumi sedangkan kebutuhan energi sangatlah banyak, maka dituntut energi pengganti untuk memenuhi kebutuhan energi nasional.

Kegiatan pengabdian kepada masyarakat dengan cara mensosialisasikan pembuatan briket batubara kulit durian dimulai dari warga RT. 019 Kelurahan 1 ilir. Wilayah ini memiliki jarak sekitar 11,7 km dari Politeknik Negeri Sriwijaya. Dengan jumlah penduduk yang cukup padat sehingga kebutuhan akan bahan bakar semakin tinggi setiap harinya. Adanya program pemerintah yang mencanangkan konversi minyak tanah menjadi gas mengakibatkan kebutuhan akan gas LPG 3 kg drastis meningkat (Rakhmanto, P.A. 2007). Seringkali dalam prakteknya, gas LPG $3 \mathrm{~kg}$ mengalami kelangkaan sehingga warga harus berkeliling ke wilayah lain untuk sekedar mendapatkan satu tabung gas yang harganya bisa mencapai Rp 25 ribu. Padahal biasanya berkisar Rp 17 ribu-Rp 18 ribu saja (Sumber : Http://palembang.tribunnews.com/2015/09/07/ ). Banyak kios sekitar menjajakan tabung gas namun terkadang ada saja sekitar dua minggu tabung - tabung yang ada di toko atau warung mereka tidak ada yang berisi alias kosong. Kalau hal ini sudah terjadi maka masyarakat hanya bisa pasrah sambil menunggu dan berharap tabung gas LPG $3 \mathrm{~kg}$ segera datang. 
Memasuki musim durian sekitar bulan Desember, Januari sampai Februari banyak sekali kios - kios bermunculan menjual durian. Harga durian di Pasar Kuto Palembang misalnya di patok kisaran 10 ribu - 30 ribu per buah . Namun sayang, hasil limbah kulit durian hanya dibuang begitu saja (Gambar 1.), padahal bentuk dari kulit durian dapat mengganggu keamanan jika dipegang oleh anak - anak yang belum faham. Berangkat dari sinilah, tim pengusul mengajak mitra warga RT. 019 Kelurahan 1 ilir untuk mengetahui manfaat dari limbah kulit durian sebagai bahan bakar alternatif. Kulit durian merupakan limbah padat yang sulit terurai di alam dibandingkan kulit buah lainnya, selain itu bau kulit durian yang sangat menyengat juga menimbulkan masalah lain. Selain itu kandungan karbon yang cukup tinggi yang terkandung di dalam kulit durian juga menjadi pertimbangan yang sangat penting.

Briket kulit durian sebenarnya hampir sama dengan briket arang tempurung kelapa dan briket arang kayu. Briket pada umumnya tidak berasap, relatif tidak menimbulkan polutan (zat pencemar) udara. Ketersediaan limbah kulit durian ketika musim durian sangatlah melimpah. Briket ini menimbulkan bau harum ketika digunakan, sehingga sangat sesuai digunakan untuk industri makanan untuk yang berskala rumah tangga maupun besar. Briket kulit durian memiliki potensi pasar terbuka luas baik pasaran lokal, domestik dan ekspor.

Briket durian adalah residu yang sebagian besar komponennya adalah karbon. Hal ini terjadi karena penguraian kulit durian, akibat perlakuan panas. Peristiwa ini dapat terjadi pada pemanasan langsung atau tidak langsung dalam timbunan, kiln, tanur tanpa atau dengan udara bebas. Penggunaan bahan bakar berbentuk briket memang lebih efektif dan efisien karena bentuk dan ukurannya dapat disesuaikan dengan keperluan. Briket arang dapat ditingkatkan kerapatannya, bentuk dan ukurannya dapat disesuaikan dengan kebutuhan, tidak kotor dan mudah transportasinya serta praktis untuk digunakan sebagai bahan bakar untuk kebutuhan rumah tangga. Jadi luaran yang diharapkan dari usulan pengabdian kepada masyarakat ini adalah produk berupa briket kulit durian dengan harga yang murah dan ekonomis.

\section{Metode Pelaporan}

Kegiatan pengabdian kepada masyarakat ini akan dilakukan dengan cara mensosialisasikan pemanfaatan limbah kulit durian. Warga RT 19 kelurahan 1 ilir akan dapat memanfaatkan limbah kulit durian sebagai produk bioenergi berupa briket. Yang tentunya dengan adanya pemanfaatan dan pengoptimalan produksi briket akan membawa dampak positif lainnya berupa peningkatan perekonomian masyarakat. Sebenarnya kehidupan orang tua kita dahulu sudah mampu menjawab permasalahan lingkungan terkait dengan menumpuknya kulit durian yang akhirnya menjadi limbah dengan cara memanfaatkan limbah kulit durian ini dengan menyusunnya di atas tempat memasak, dan setelah kering di bakar sebagai alat pengusir nyamuk pada malam hari atau sebagai bahan bakar memasak sehingga ini merupakan indikasi bahwa bahan ini dapat diolah menjadi produk - produk tertentu yang bermanfaat dan berdaya guna. Lebih lanjut disebutkan bahwa apabila dihubungkan dengan kebiasaan orangorang tua zaman dulu yang memanfaatkan kulit durian ini untuk bahan bakar pengusir nyamuk atau bahan bakar untuk memasak maka ini terbukti berdasarkan hasil penelitian menunjukkan bahwa nilai kalor kulit durian yang diperoleh menunjukkan angka sebesar $3786,95 \mathrm{kal} / \mathrm{gram}$ dengan kadar abu rendah sebesar 4 persen. Jika dibandingkan dengan nilai kalor arang dari kayu alaban sebesar $5422,74 \mathrm{kal} /$ gram maka nilai ini tidak terlalu jauh berbeda. Untuk produk briket arang, kedua bahan ini dapat dikombinasikan sehingga diharapkan nilai kalornya menjadi meningkat. Dari pengujian sifat mekanika menunjukkan bahwa nilai keteguhan lengkung (Modulus of Elastisity) produk papan partikel dari limbah kulit durian yang menggunakan perekat mineral (semen) adalah sebesar 360 $\mathrm{kg} / \mathrm{cm}^{2}$ dengan nilai keteguhan patah (Modulus of Rupture) sebesar $543 \mathrm{~kg} / \mathrm{cm}^{2}$ (Hatta, V. 2007. Apabila dilihat dari besarnya angka tersebut dan dibandingkan dengan nilai keteguhan lengkung dan nilai keteguhan patah kayu pejal/utuh maka produk papan partikel dari bahan baku kulit durian ini termasuk dalam klasifikasi kelas kuat III cocok digunakan sebagai bahan konstruksi di bawah atap dengan beban ringan sampai sedang.

Kegiatan pemanfaatan kulit durian sebagai bahan bakar berupa briket ini dapat dilakukan 
oleh warga RT 019 kelurahan 1 ilir sepanjang musim durian. Dengan adanya kegiatan pemanfaatan briket berbahan dasar kulit durian ini, tentunya akan menambah pengetahuan tentang adanya energi alternatif berupa briket dari limbah kulit durian. Pengetahuan tersebut diharapkan dapat dikembangkan dan diaplikasikan lebih luas oleh warga RT 019 kelurahan 1 ilir sehingga menjadi sebuah bidang wirausaha dengan efek samping positif berupa budaya hidup sehat, bersih dan ekonomis. Melalui kegiatan pemanfaatan briket berbahan dasar kulit durian ini memberikan sebuah solusi terkait masalah menumpuknya limbah kulit durian. Kulit durian yang selama ini mengganggu kebersihan lingkungan di wilayah warga, khususnya pada saat musim panen durian. Hal yang mendasari besarnya minat masyarakat untuk memanfaatkan limbah kulit durian sebagai bahan bakar briket adalah keselarasan dengan lingkungan hidup dan bidang pekerjaan masyarakat yang biasa menjadi pedagang musiman ketika masa panen durian tiba. Bahan dasar pembuatan briket yang berupa limbah kulit durian memudahkan masyarakat tersebut menjaga konsistensi pengadaan bahan baku dari bahan bakar alternatif tersebut, tentunya khusus pada saat musim panen buah durian. Faktor peningkatan ekonomi juga menjadi satu daya tarik masyarakat dalam mengelola briket berbahan kulit durian tersebut. Kulit durian yang merupakan bahan dasar pembuatan briket ini, sebelumnya hanya menumpuk menjadi limbah di lingkungan tempat berjualan dan tidak dapat memberikan nilai ekonomis. Sedangkan setelah melalui proses pengolahan dan menjadi bahan bakar berupa briket, produk ini mempunyai nilai jual yang cukup tinggi .

Dalam pelaksanaan kegiatan dilapangan, berdasarkan data pengamatan dan hasil beberapa penelitian maka akan dibuat briket arang kulit durian dengan tahapan - tahapan sebagai berikut yaitu :

- Mempersiapan alat dan bahan

- Mencampur media

- Membakar media

- Melakukan pencetakkan

- Melakukan Proses Peleburan

- Melakukan Proses Pengeringan

Dari hasil pembuatan $1 \mathrm{~kg}$ briket kulit durian akan dihasilkan beberapa keping briket yang dapat digunakan dan akan diketahui berapa lama waktu pembakaran efektif. Kemudian harga $1 \mathrm{~kg}$ briket kulit durian akan dapat diasumsikan dengan $1 \mathrm{~kg}$ briket batubara untuk waktu pembakaran efektifnya. Dari hasil tersebut akan terbukti bahwa penggunaan briket kulit durian dapat lebih murah dan bernilai ekonomis dibandingkan penggunaan minyak tanah dan menjawab kelangkaan persediaan tabung gas LPG $3 \mathrm{~kg}$ yang masih sering terjadi di kalangan masyarakat.

\section{Hasil Pelaksanaan Program}

Para tim pengusul kegiatan pengabdian kepada masyarakat sosialisasi pemanfaatan briket kulit durian kepada warga RT. 019 Kelurahan 1 ilir Palembang Sumatera Selatan adalah para dosen program D-IV Teknik Energi yang memiliki keahlian di bidang energi baru dan terbarukan. Dari berbagai pengalaman penelitian dan kepedulian terhadap lingkungan maka dikeluarkan gagasan untuk melakukan kegiatan ini. Di era energi mahal, solusi energi alternatif sangat diperlukan sehingga untuk menjawab tantangan dunia global ini maka para pengusul akan mensosialisasikan pengetahuan pemanfaatan limbah kulit durian menjadi produk yang berdaya guna dan bermanfaat serta bernilai ekonomis berupa briket kulit durian. Program studi D-IV Teknik Energi sesuai dengan visi misinya berusaha menjadi program studi yang mampu menjadi pioner pembangun bangsa Indonesia khususnya warga Sumatera Selatan untuk terus berusaha bangkit dari krisis bahan bakar yang juga menjadi persoalan dunia. Tentunya diharapkan dengan luaran produk yang dihasilkan dapat mengkolaborasikan hidup bersih, sehat dan ekonomis sebagai kearifan lokal bangsa Indonesia.

Dari hasil pelaksanaan program sosialisasi pemanfaatan limbah kulit durian menunjukkan antusiasme masyarat ketika ditayangkan video pembuatan limbah kulit durian. Dari pertanyaan dan diskusi yang dilontarkan oleh warga yang hadir menunjukkan betapa mereka termotivasi untuk membuat briket kulit durian apalagi dengan adanya musim durian, terasa mudah sekali mendapatkan limbah kulit durian yang hanya dibuang sehingga cukup mengganggu kebersihan lingkungan. Dalam pelaksanaan sosialisasi ini juga diberikan modul pembuatan briket dari limbah kulit durian. Diharapkan dengan adanya sosialisasi 
ini diharapkan masyarakat mampu memanfaatkan dan membuat limbah kulit durian menjadi briket sehingga diperoleh sumber bahan bakar alternatif di saat LPG terasa langka di pasaran. Masyarakatpun tidak perlu merasa khawatir lagi apabila terjadi krisis LPG karena mereka telah memiliki keterampilan dalam mengolah limbah kulit durian menjadi briket.

\section{Kesimpulan}

Berdasarkan uraian pada bab sebelumnya dapat disimpulkan bahwa :

a. Dengan adanya kegiatan pengabdian ini maka masyarakat dapat memanfaatkan limbah kulit durian untuk meningkatkan kualitas briket batubara

b. Pemanfaatan limbah kulit durian dalam pembuatan briket batubara dapat mengurangi dampak pembuangan limbah kulit durian ke lingkungan

c. Keunggulan briket batubara kulit durian adalah tidak bersifat polutan, pemakaian relatif lama, kerapatan arang dapat ditingkatkan serta menimbulkan bau harum sehingga cocok untuk industri makanan

d. Peluang usaha dari briket batubara kulit durian cukup besar karena mengingat harga bahan bakar seperti minyak tanah relatif mahal

\section{Referensi}

Adan, I.U. 1998. Membuat Briket Bioarang. Teknologi Tepat Guna. Yogyakarta. Kanisius.

Hatta,V. 2007. Manfaat Kulit Durian Selezat Buahnya. Jurnal. UNLAM.

Http://www.antaranews.com/foto/57620/sentra -durian-pasar-kuto, diakses tanggal 12 Juni $\underline{2016}$

Http://palembang.tribunnews.com/2015/09/07/ di-palembang-gas-3-kg-langka-apa-kerjapemerintah-dan-pertamina, diakses tanggal $\underline{12 \text { Juni } 2016}$

Https://www.academia.edu/8385602/Pembuata n Briket Kulit_Durian, diakses tanggal 12 Juni 2016
Http://engineeringforbetterlife.blogspot.co.id/2 011/06/briket-kulit-durian-salah-satupilihan.html, diakses tanggal 12 Juni 2016

Rakhmanto, P.A. 2007. Menyoal Substitusi Minyak Elpiji, Jurnal. 